\title{
Scanning Electromicroscope as a Tool to Re-describe Isolates of Varroa destructor from Nine Different Egyptian Governorates
}

\author{
Sally F. Allam ; A.Y. Zaki** and S. M. O. El-Bishlawy" \\ ${ }^{*}$ Department of Zoology and Agricultural Nematology, Fac. of Agric., Cairo Univ. \\ ${ }^{*}$ Plant Protection Research Institute, Agric. Res. Center, Giza, Egypt.
}

\begin{abstract}
The new results according to Anderson \&Trueman (2000) and Zaki (2009) determining the specific statuses of Varroa in Egypt were identical to that of the Korean genotype of $V$. destructor. The honeybee mite Varroa destructor specimens collected, from nine governorates repesenting ten regions: Arish and Rafah (North Sinai), Esmailia, Minia, Giza, Gharbia, Qalubia, New Valley (Dakhla Oasis), Alexandria and Fayoum governorates examined and measured. Observations of characters under scanning electronmicroscope were analyzed.
\end{abstract}

Key words: Acari, Varroidae, Varroa jacobsoni, Varroa destructor, honeybee, parasite, SEM, Egypt.

\section{INTRODUCTION}

Varroa mites were firstly discovered more than 100 years ago on the Asian honey bee (Apis cerana) in Java, Indonesia and named Varroa jacobsoni (Oudemans, 1904). They were assigned to a new genus, Varroa, and eventually to a new family, Varroidae (Delfinado-Baker and Baker, 1974). At present, the genus contains four species.

Since the initial discovery, it has become clear that Varroa mites are native brood parasites of a group of cavity nesting Asian honey bees that are closely related to A. cerana. Varroa mites that have since utilized A. mellifera as a host are all members of $V$. destructor; the most recently described species of the genus, and are native to A. cerana in northeast Asia (Anderson and Trueman, 2000). It is possible that new Varroa species await discovery. Prolonged coevolution of $V$. destructor and $A$. mellifera may yet see these mites also becoming genetically diverse (Oldroyd, 1999), particularly as they gradually adapt to exist on isolated populations of A. mellifera. However, the movement of bee stocks around the world by man and the beekeeping practice of requeering large numbers of $A$. mellifera colonies on a regular basis with queens from a common source will, to some extent, counter natural evolutionary processes that may eventually lead to Varroa speciation on $A$. mellifera. Various methods have been used over the years to determine variation within Varroa, of which the most common and simple methods which deal with measurements of mite physical characteristics (morphology). The initial discoveries of $V$. jacobsoni on A. cerana, $V$. underwoodi on $A$. cerana and $V$. rindereri on $A$. koschevnikovi all resulted from morphological studies. More recently, molecular methods have helped to clarify Varroa taxonomy and being useful for identifying genetic variation within species and even identifying cryptic species. These methods, described below, played a crucial role in the discovery of the new species, $V$. destructor, and not being $V$. jacobsoni as previously thought (Anderson and Trueman, 2000). The taxonomy of Varroa on Asian honey bees can be summarized as follows by Lindquist et al., 2009: V. jacobsoni (Oudemans, 1904) $V$. underwoodi (Delfinado-Baker and Aggarwal, 1987) $V$. rindereri (De Guzman and Delfinado-Baker, 1996) $V$. destructor (Anderson and Trueman, 2000).

The taxonomic status of three genetically distinct Varroa types that infest $A$. cerana in the Philippines remains unresolved at this time (Anderson, 2000; Anderson and Trueman, 2000).Mites of just two 'haplogroups' of $V$. destructor (see section 2.4.5. 'Haplogroup and haplotype identification') have colonized A. mellifera globally. Of the two, those belonging to a Korea haplogroup are the most common and widespread on A. mellifera, being present in Europe, the Middle East, Africa, Asia, the Americas and New Zealand. At present Australia remains the only large landmass on earth on which the resident $A$. mellifera are free of Varroa. This mite has been known as a dangerous pest of honeybee around the world (Sammataro et al. 2000). Varroa jacobsoni Oud. was recorded for the first time in Egypt in 1983 (Wienands, 1988), and within the last few years it becomes a subject of concern to beekeepers where the majority of apiaries in the Egyptian governorates were destroyed (Abd AlFattah et. al., 1991). Varroa causes a serious damage by feeding on heamolymph of larvae, pupae and adults, and by transmitting or activating viral diseases, (Sammataro et. al., 2000; Martin, 2001). Further studies based on isozyme techniques (Issa 1989; Biasolo 1992) and random amplification of polymorphic DNA (RAPD) (Kraus \& Hunt 1995; De Guzman et. al., 1997) showed frequency differences among different populations of $V$. jacobsoni, suggested that the entity known as $V$. jacobsoni is more than one species. According to Anderson and Trueman (2000), the identity of Varroa mites 
infesting $A$. mellifera in 32 countries was investigated using mtDNA Co-I gene sequences and morphological characters, all were found to be $V$. destructor, and not $V$.jacobsoni as had been assumed. However, only 2 of the six $V$. destructor genotypes found on $A$. cerana were parasiting $A$. mellifera. The most common was a Korean genotype of $V$. destructor, so-called because its primary host was $A$. cerana in Korea. It was found on $A$. mellifera in Europe, the Middle East, the Americas, Africa and Asia. Also, Awad et al., 2011 found that mtDNA sequences which obtained from all 10 samples collected from $A$. mellifera in Egypt were identical to that of the Korean genotype of $V$. destructor. The purpose of this paper is to determine the specific Egyptian Varroa morphological characters by using Scanning electromicroscope as a tool to redescribe isolates of Varroa destructor from ten regions belonging to nine different Egyptian governorates.

\section{MATERIALS AND METHODS}

Samples of adult female Varroa mites (1-2 mite/colony) were collected from three hybrid carniolan colonies at various locations in Egypt. These locations belong to nine governorates representing ten regions: Al-Arish and Rafah (North Sinai), New Valley (Dakhla Oasis), Qalubia, Gharbia, Esmailia, Minia, Giza, Fayoum and Alexandria governorates. Mites were collected alive from the bodies of adult workers, drone bees, capped worker broods, or drone brood cells and preserved in $70 \%$ ethanol. To confirm the specific identity, mite morphology was examined using light microscopy and the length and width of each female were measured individually. These measurements, inA micrometers $(\mu \mathrm{m})$, were taken from five females, obtained from each region and prepared in Hoyer's medium on glass microslides.

For observation of characters under scanning electron microscope, alive specimens were put through served bath of distilled water in an attempt to clean them of debris. They were, then, briefly submerged in distilled water near boiling point in order to force prostration of appendages. Specimens were fixed in glutaraldhyde of $3.5 \%$ concentration for 6 hours then dehydrated in ethyl alcohol and dried using the critical point procedure. Then, they were individually affixed to stubs using double-sided sticky tape, and coated with gold-palladium in a sputter coater, (microscopy was performed with JEOL GM 4200) (Fashing et. al., 2000).

Also, cells of worker and drone brood were uncapped. All mite individuals, either attached to immature bee or found on the cell wall were collected with their exuvia and mounted on glass slides, using
Hoyer's medium. Slides were examined by phasecontrast microscope and identifications of the developmental stages were made using the morphological characteristics described by (Delfinado-Baker, 1974) and (Delfinado-Baker, 1984). Mounted Varroa stages were examined and twenty morphological characteristics were measured with a micrometer.

\section{RESULTS AND DISCUSSION}

The characteristics of Varroa destructor in Egypt are summarized in table 1 and figs 2-11. Nomenclature is that of Delfinado-Baker, 1974 and Delfinado-Baker and Agarwal, 1987.

Anderson and Trueman, 2000 reported that the identity of Varroa mites infesting Apis mellifera in 32 countries investigated using mtDNA Co-I gene sequences and morphological characters, all were found to be $V$. destructor and not $V$. jacobsoni as had been assumed. However, only 2 of the $\operatorname{six} V$. destructor genotypes found on $A$. cerana were parasiting $A$. mellifera. The most common was the Korean genotype of $V$. destructor, so-called because its primary host is $A$. cerana in Korea. It was found on $A$. mellifera in Europe, the Middle East, the Americas, Africa and Asia.

Also, when we used SEM in description of female $V$. destructor after we sure $V$. destructor by DNA sequences (Awad et al., 2010 and Awad et al., 2011). Twenty characters distinguished and determined in $V$. destructor in Egypt, in Table 1.

\section{Description of Varroa destructor in Egypt: \\ Gnathosoma:}

The gnathosoma is situated anteroventrally and is visible through the dorsum.

\section{1- Hyposome:}

Scan surface of hypostome determines long striations beside the edges of hypostome and trasverse striations near its tip consist of island transverse striations (Fig. 5c); three paris on hypostome on one line. this character differs from that of DelfinadoBaker, 1974 who found three paris of setae in one row also. Hoever, Delfinado and Aggarwal, 1987 found these setae not in line, Table 1.

\section{2- Chelicera:}

Has bidentate (two teeth) on apical half one sharptipped and smaller than other blunt tipped tooth (Fig. 7b), (Fig. 10h, Fig. 10i) with movable digit only (Fig. $7 \mathrm{~b}$ ) and fixed digit not found dorsal seta and fissures present. These characters agree with Delfinado and Aggarwal, 1987.

\section{3- Palp of gnathosoma:}

Has apotele bifurcate, one long and the other is 

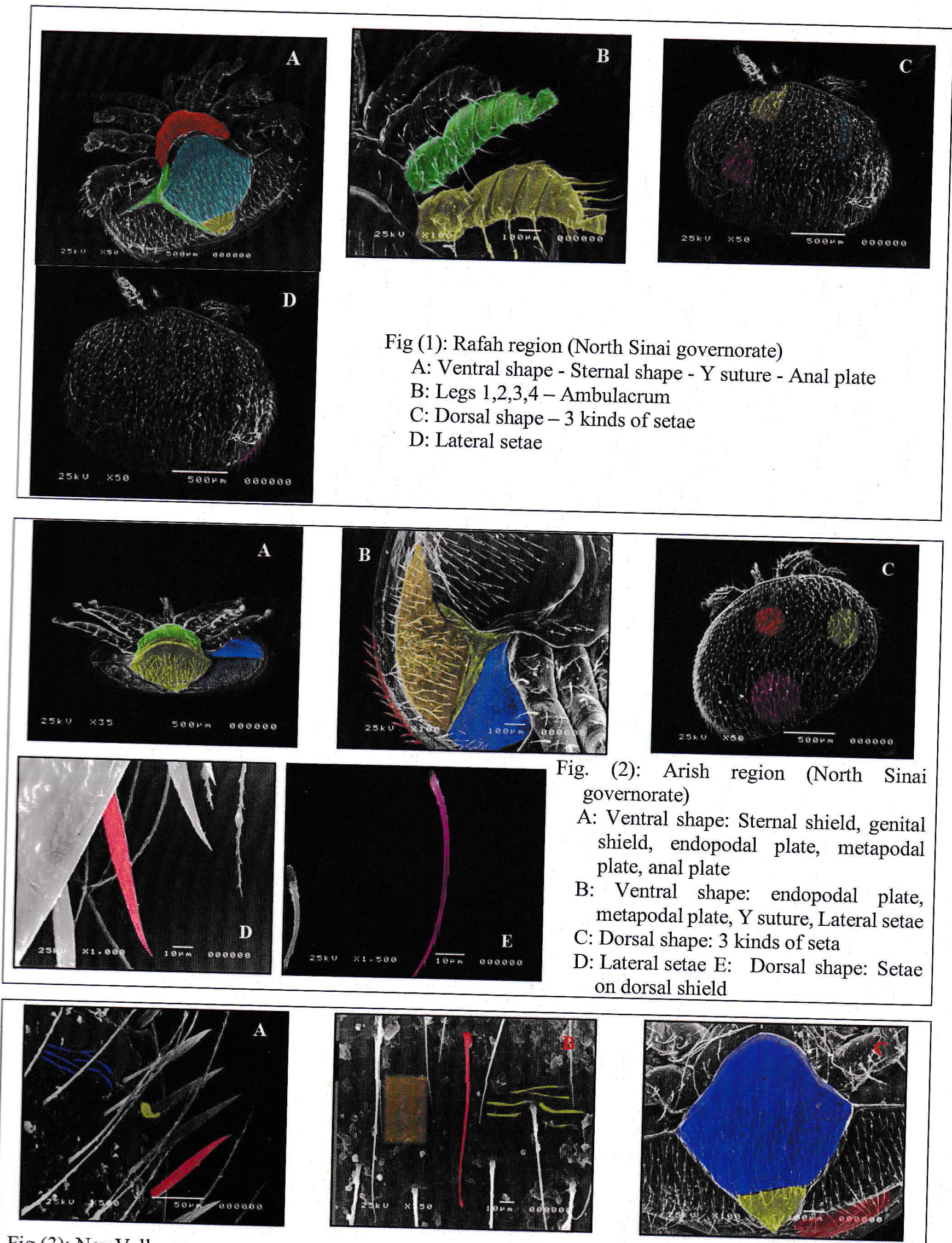

Fig (3): NewVally governorate

A: Lateral setae on dorsal shield, striation on dorsal shape B: Striation on dorsal shape, Lateral setae on
dorsal shield C: Genital shield, endopodal dorsal shield C: Genital shield, endopodal plate, metapodal plate, anal plate 

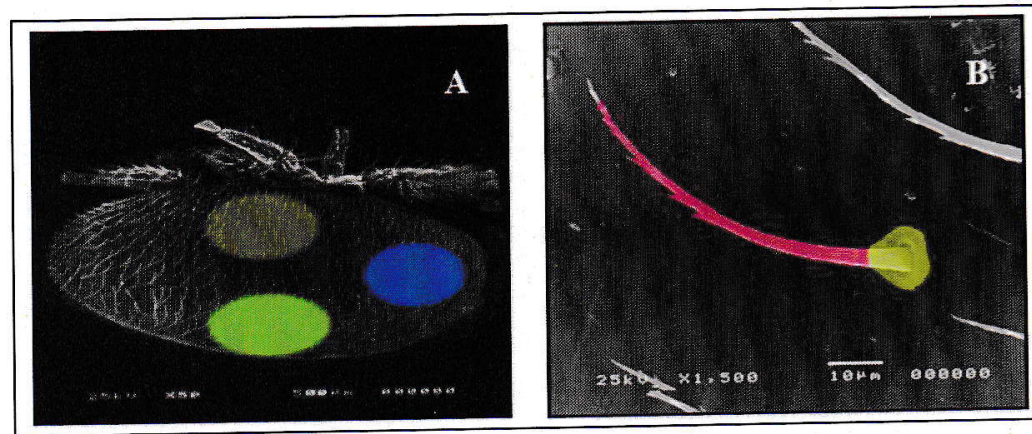

Fig (4): Qaluobia governorate

A: Dorsal shape: 3 kinds of setae (specially barbed setae)

B: Striation on dorsal shape, dorsal setae on dorsal shield
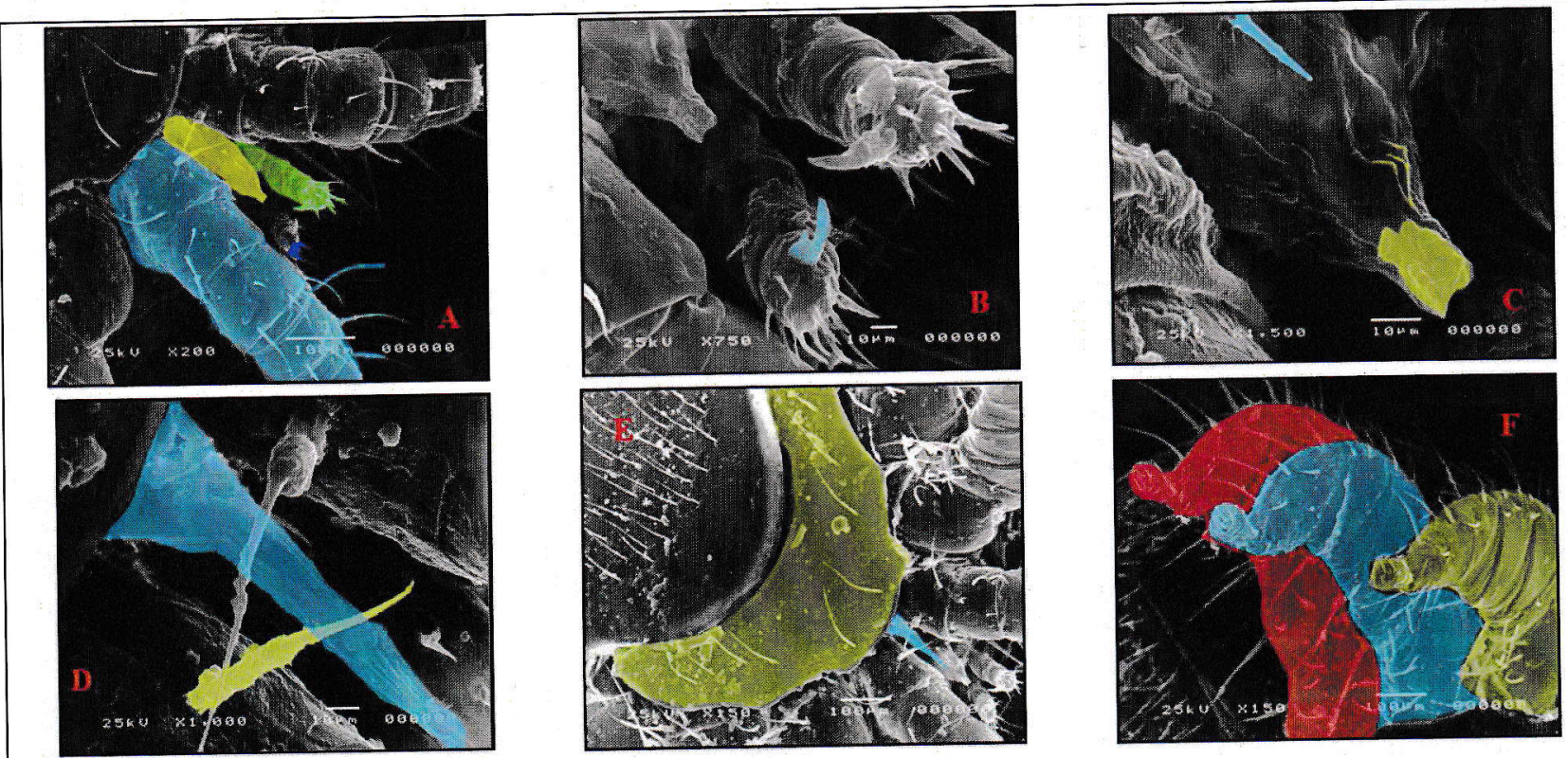

Fig (5): Gharbia governorate

A: Ventral shape: hypostome, palp, setae on palp tarsus, Leg 1

C: Ventral shape: surface of hypostome, hypostomal setae setae on leg 1

E: Ventral shape: sternal plat

B: Apotele on palp

D: Ventral shape: tritosternum shield,

F: Legs 2, 3, 4
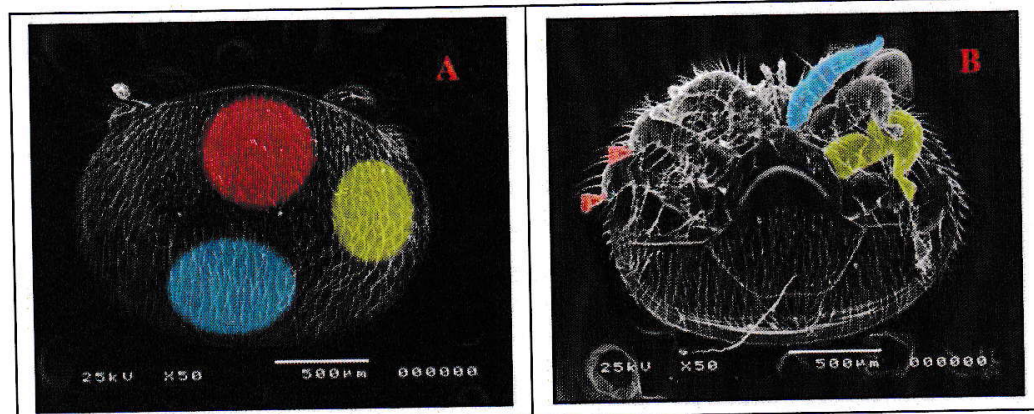

Fig (6): Esmailia governorate

A: Dorsal shape: 3 kinds of setae

B: Ventral shape: Legs 1, Legs

3, Ambulacrum
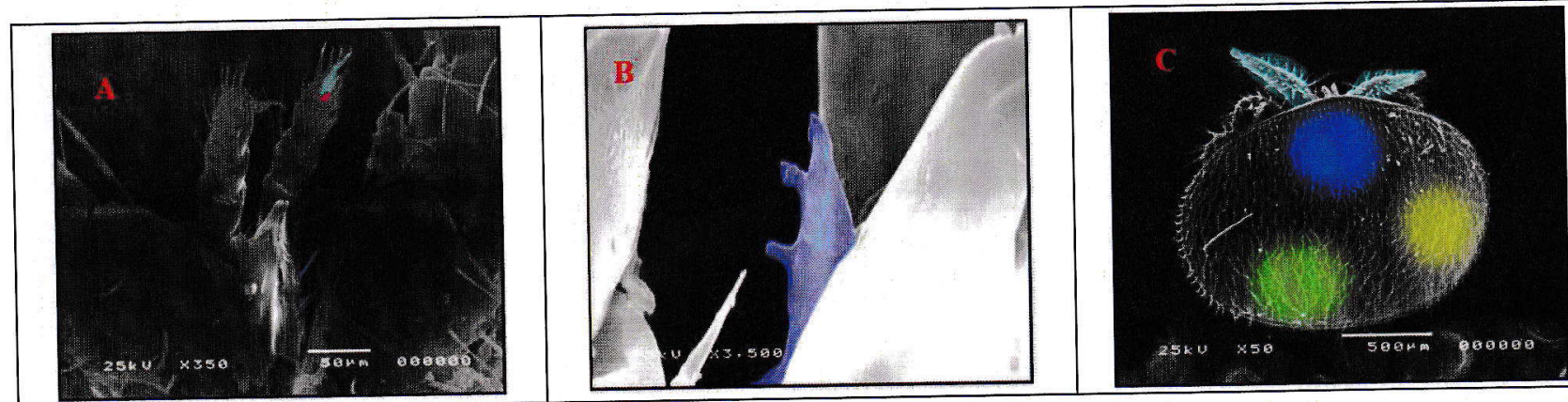

Fig (7): Minia governorate

A: Ventral shape: 3 setae on hypostome, apotele with bifurcate B: Ventral shape: chlicera with two teeth

C: Dorsal shape: 3 kinds of setae 

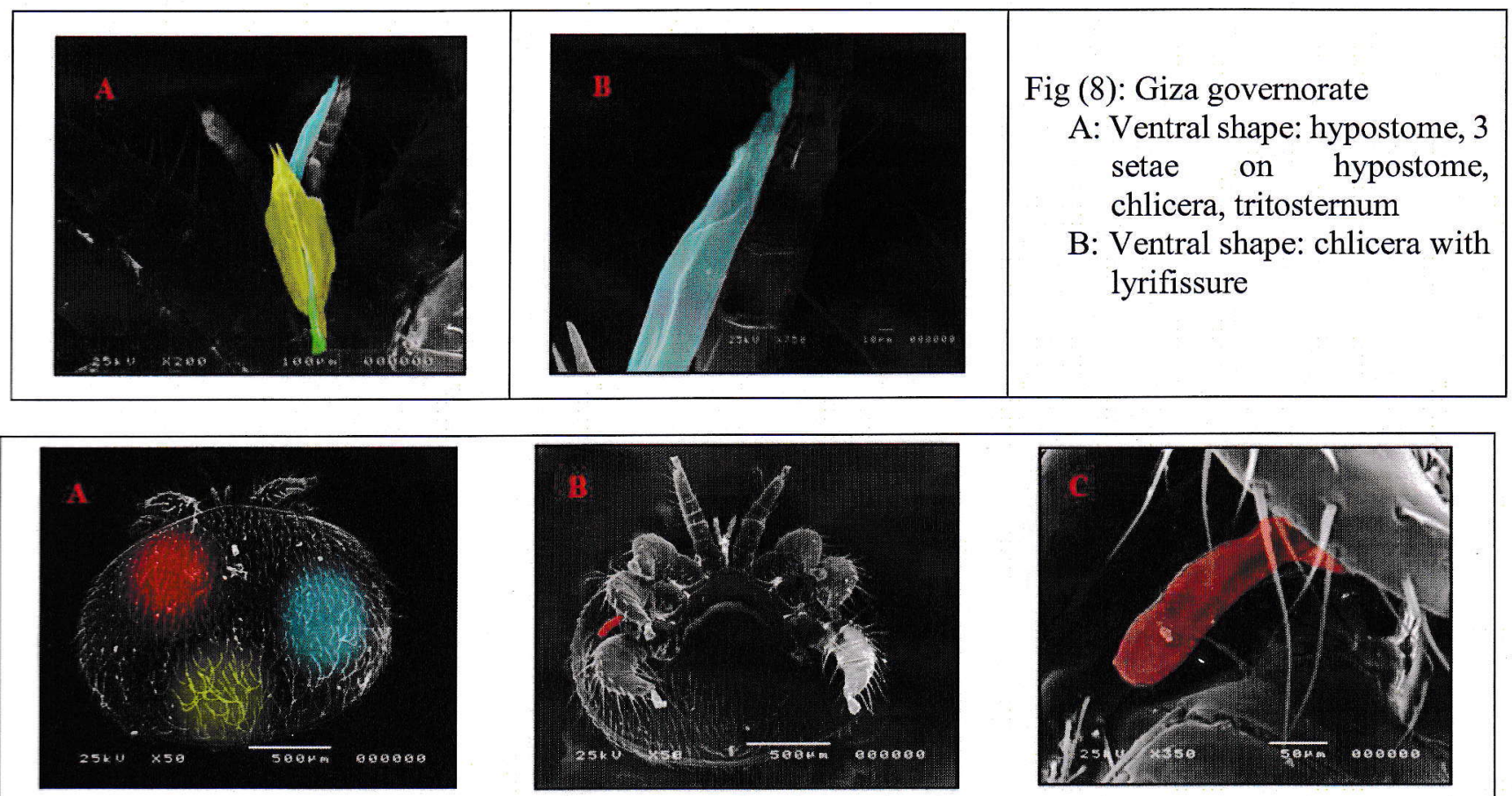

Fig (9): Fayoum governorate

A: Dorsal shape: 3 kinds of setae

B: Ventral shape: pritreme between leg 3 and leg 4

C: Ventral shape: pritreme

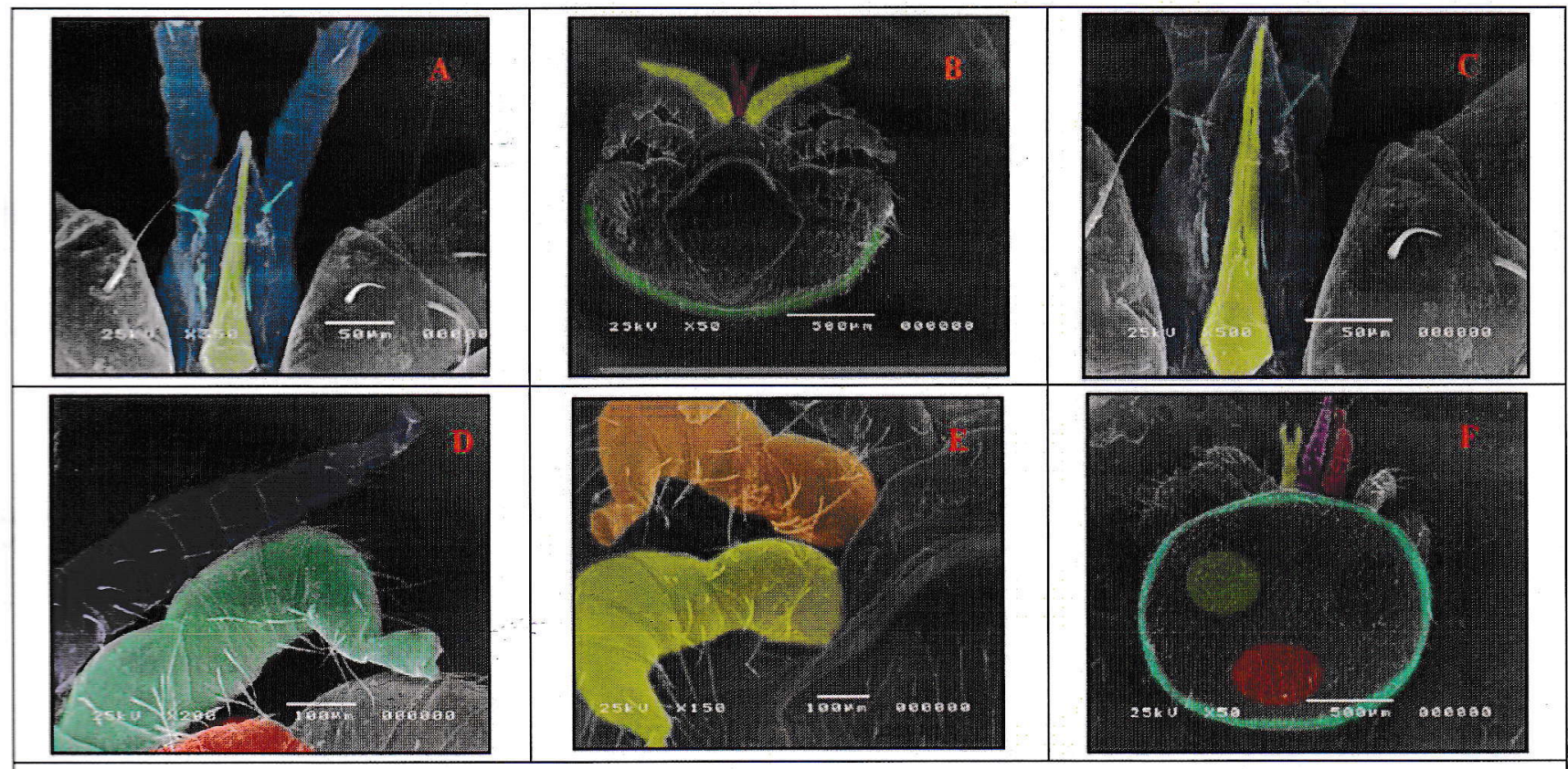

Fig. (10): Alexandria governorate

A: Ventral shape: hypostome, 3 setae on hypostome, tritosternum

B: Ventral shape: hypostome, leg 1, the edges of Varroa

C: Ventral shape: hypostome, 3 setae on hypostome, tritosternum

D: Leg 1, leg 2, edge of peritreme

E: Leg 3, leg 4

F: Dorsal shape: the edges of Varroa, leg 1, leg 2, 3 kinds of setae 


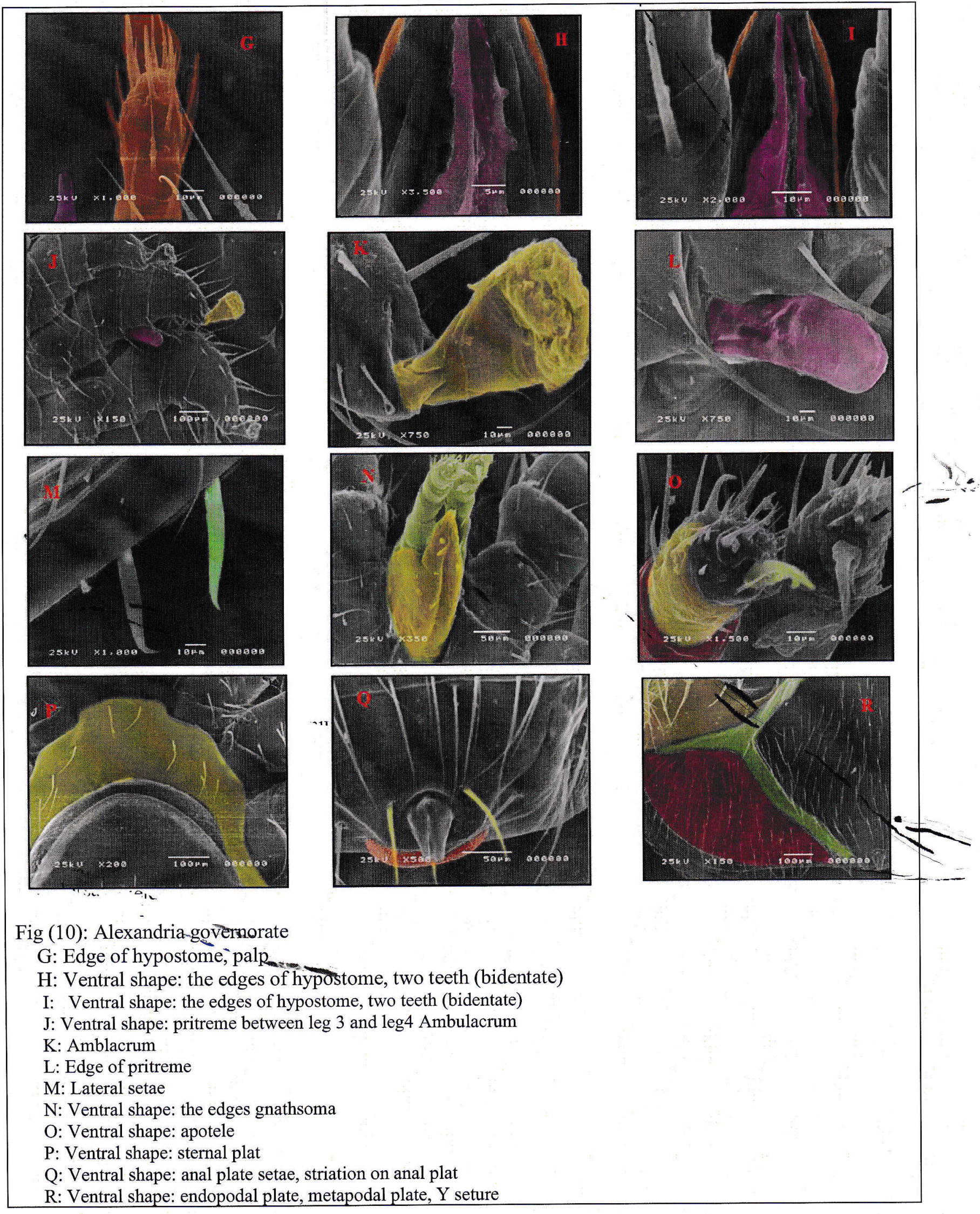


Table (1): Morphologgical characters of $V$. destructor (female) in Eygpt

\begin{tabular}{llll}
\hline \multicolumn{1}{c}{ Morphological characters } & V. destructor in Eygpt & \multicolumn{1}{c}{ V. jacobsoni } & V. underwoodi \\
\hline Maximum length & $4128^{*}(1152-1728)$ & $1135-1198$ & $741-780$ \\
\hline Maximum width & $4992(1632-1728)$ & $568-1744$ & $1151-1168$ \\
\hline Length of chelicera & 192 & - & - \\
\hline Chelicera seta & With & Without & With \\
\hline Chelicera lyrifissures & With & With & With \\
\hline Palpal chaetotaxy & $1,2-3,2-3,7-9,10-12$ & $1,2-3,2,7-8,12$ & $1,3,2,10,12$ \\
\hline Gnathosomal setae & 3 in on line & Longitudinal & Hyp.2 cleary not in line with \\
& & row & hyp.1 and 3(palp coxa setae \\
\hline Deutosternum & With denticles & Smooth & denticles \\
\hline Endopodal & $6-11$ setae & $5-8$ setae & $6-9$ setae \\
\hline Sternal setae + lyrifissures & $4-8$ pairs of setae & $5-6$ pairs & 4 pairs \\
& $4-6$ pairs of pores & $4-5$ pores & 4 pores \\
\hline Distance between St1-St1 & $114.176(71.04-192)$ & - & - \\
\hline Distance between St2-St2 & $216.32(192-245.76)$ & - & - \\
\hline Longitudinal distance between St1-St2 & $131.68(76.32-222.72)$ & - & - \\
\hline Width of genital plate & $466.67(656-672)$ & - & - \\
Count of 1/2 of setae on shield & $40-56$ & & - \\
\hline Width of Anal shield & $214.08(201.6-222.72)$ & - & - \\
\hline Width of Metapodal shield & $316.8(288-355.2)$ & - & - \\
\hline Length of Metapodal shield & $704(672-768)$ & - & - \\
\hline Length of Tarsus & $160(105.6-192)$ & - & $18-19$ \\
\hline Number of Marginal setae (lateral) & $19-31$ setae & $21-23$ & \\
\hline * Dimensions are in micrometers. & & & \\
\hline
\end{tabular}

short (Fig.5b - Fig.7a - Fig.8a - Fig.10b, n, o). Numbers of satae on palpal trochanter, femur, genu, tibia, and tarsus are 1, 2-3,2-3, 7-9, 10-12, respsctivly (Table 1). These formula on palpal chaetotaxy differs from Varroa jacobsoni (Delfinado-Baker, 1974) and palpal chaetotaxy of Varroa underwoodi (DelfinadoBaker and Agarwal, 1987).

\section{4- Deutosternum:}

Has denticles, and this agrees with that mentioned by Delfinado-Baker and Agarwal, 1987 who reported that the deutosternum with denticles in $V$. underwoodi while differs from $V$. jacobsoni, Delfinado-Baker 1974, who reorted that the deutosternum was smooth. Table 1.

\section{B- Ventral shield:}

All ventral shields extensively developed and sclerotized with surface lightly and finely striatereticulate this agrees with Delfinado and Aggarwal, 1987 who determine the same description.

\section{1- Tritosternum:}

The basis of tritosternum is triangle, is contacts with sternal shield of Varroa, the triangle extends to the hypostome. Tritosternum is bipartite (Fig. 7a), membranous, laciniae is tapring and separtly serrate (Fig. 5a \& d, Fig. 7a, Fig. 8a) this description of tritosternum agrees with those by Delfinado-Baker, 1974 and Delfinado-Baker and Aggarwal, 1987who gave similar description.

\section{2- Sternal shield:}

From table (1) Sternal plate is extending from anterior margin of coxae 2 to coxae 4 , occuping the area between coxa 1 and coxa 4 behind tritosternum; with 4-8 pairs of setae and 4-6 pairs of pores. The numbers of setae differs from delfinado-Baker, 1974 who reported the occurrence of 5-6 pairs sternal setae and 4-5 pores in $V$.jacobsoni. Also, delfinado-Baker and Aggarwal, 1987 found that $V$. underwoodi has 4 pairs of setae and pores in the sternal shield (Table 1, Fig. 7a, Fig. 10p). between sternal 1 (st1) ranged from $71.04-190 \mu \mathrm{m}$, between sternal 2 (st2) ranged from $192-245.76 \mu \mathrm{m}$ and longitudinal distance between (st1-st2) ranged from $76.32-222.72 \mu \mathrm{m}$.

\section{3- Genital shield:}

Densely covered with simple setae. occuping the area between coxa 4 until anal plate on the posterior region from the venteral shields, behind sternal shield, between the suture Y shape which extends lateral to genital shield. (Fig.1a\&b, Fig.2a\&b, Fig.3c, Fig.6b, Fig.9b). The width of genital shield ranged from 656 to $672 \mu \mathrm{m}$. and the half number of setae ranged from 40 to 56 , also genital plate is wider than long. The anterior porision of genital plate with striations and empty from setae (Fig 2b). This description agrees with that by Delfinado-Baker and Aggarwal (1987) who stated that genital shield densely covered with setae at posterior $2 / 3$, mostly of uniform length and smooth. 


\section{4- Endopodal shield:}

Endopodal plate is well developed, half circuling posterior border of coxa 4 . A suture in $\mathrm{Y}$ shape is between endopodal plate from one side, metapodal plate plate on the second side and sternal and genital plate on the third side (Fig. 2b, Fig. 10r). The description of endopodal plate agrees with that by delfinado-Baker (1974) of endopodal plate in characters of the genus Varroa; but the suture in Y shape was not descriped by delfinado-Baker (1974) and delfinado-Baker and Aggarwal (1987). From Table (1) endopodal plate has $8-10$ setae on the posterior margin and with a little striation.

\section{5- Metapodal shield:}

Metapodal shield broadly is triangular, densely covered with simple setae (Fig. 2b, Fig.3c, Fig. 10r). Width of metapodal shield ranges from 288 to 355.2 $\mu \mathrm{m}$, the length of metapodal shield ranges from 672 to $768 \mu \mathrm{m}$ (Table 1). These description agrees with that by Delfinado-Baker (1974) and delfinado-Baker and Agarwal (1987).

\section{6- Anal shield:}

Width of anal shield ranges from 201.6 to 222.72 $\mu \mathrm{m}$; anal shield triangular, separated from genital shield, anal plate small bearing 3 setae, paranals situated on each side of anus, with one post anal, anus terminal. Anal plate has striations and the posterior edge has 8 rows of punctation (Table 1) (Fig. 3c, Fig. $10 q)$. This description agrees with those of DelfinadoBaker (1974) and delfinado-Baker and Agarwal (1987) who mentioned that anal plate is small and paranals situated on each side of anus.

\section{C- Peritreme:}

It is visible on ventral view in a lateroventral position between the third and fourth leg.

The movable emergment pertrime lies flat along the venter laterad of legs 3 and 4 (Fig.9b) but can be lowered $90^{\circ}$ on the surface of body during respiration (Fig.10J, L). The sclerotized pritremal groove consistes of an ascending and a shorter descending arm forming a hook around the tip of the peritreme. The intrior of the groove and stigmatal atriumare lined (Fig. 9c) with micropapillae (microtrichae) (Fig.10L). this description agrees with that by Bruce et al.,(1997) who reported that the remainder of the peritreme is a sac-like structure that is continuous with the body hemocoel; also agrees with that by Richard et al., (1990) who observed that a curved peritreme which continues with a tubular diverticle that connects with the trachea. This mechanism enables the adult female to breathe inside the capped cell where the quantity of oxygen is reduced and liquid is sometimes present.

\section{D- Dorsal shield: \\ Dorsal chaetotaxy:}

Surface of dorsal plate covered with numerous finely barbed setae of varying lengths, ornamented with striation and polygonal network of simple line (Fig.1d, Fig. 2c\&d, Fig.3b, Fig.4a\&b, Fig.6a, Fig.7c, Fig.8a, Fig.10f).

\section{Marginal (lateral setae):}

Number of marginal setae ranges from 19 to 37; these numbers disagree with delfinado-Baker (1974) who found 21-23 setae in Varroa jacobsoni and delfinado-Baker and Agarwal (1987) who found 1819 in $V$. underwoodi. These setae are with narrow thickened margin, broadened anterio-laterally, dorsally short the tip dagger (Table1, Fig. 1d, Fig. 2e, Fig. 3a, Fig. 10m)

\section{E- Legs:}

There are four pairs of robust, squat legs, formed by seven segments: coxa, trochanter, femur, genu, tibia, metatarsus and tarsus, with terminal membranous ambulacra without claw or apotele. The ambulacra comprises an adherent sucker.

Ambulacra are well developed, membranous, with strong sclerotic and without claws (Fig.1b, Fig. $10 j \& k$ ). These characters agree with those by delfinado-Baker and Aggarwal (1987). Length of tarsus ranges from 105.6 to 192 . Legs 7 segmented with metatarsi except the first leg has not. Leg chaetotaxy formulas as in Table (1) and the Figures (Fig. 1a\&b, Fig. 2a\&b, Fig. 5a\&f, Fig.6b, Fig. 7a, Fig. 8a, Fig.9b, Fig.10b-e-d-j\&n) representing coxa, trochanter, femur, genu, tibia, metatarsus and tarsus.

Leg 1: 2, 4, 10, 11-12, 12, 0, 34

Leg 2: 2, 4, 5, 4, 8, 8, 13

Leg 3: 1-2, 4-5, 3-6, 11, 11, 4, 13

Leg 4: $1,6,5-7,9,10,4,12-13$

These results agree with those by Delfinado-Baker (1974) who found that the numbers of setae was the same number in almost cases but different numbers in few cases.

\section{REFERENCES}

Abd Al-Fattah, M. A.; Nour, M. E. and El-Shemy, A. A. M. 1991. Efficacy of some chemical compounds to control Varroa mite (Varroa jacobsoni Oud.) in honeybee colonies in Egypt. Egypt. J. Appl. Sci., 6 (12): 139-152.

Anderson, D. L. 2000. Variation in the parasitic bee mite Varroa jacobsoni Oud. Apidologie, 31: 281-292.

Anderson, D. L. and Trueman, J. H. W. 2000. Varroa jacobsoni (Acari: Varroida) is more than one 
species. Experimental \& Applided Acarology, 24 165-189.

Awad, S. N.; Allam, S. F. M.; Rizk, M. A.; Hassan, M. F. and Zaki, A.Y. 2010. Fingerprinting and assessment of genetic variability of Varroa destructor in Egypt. Journal of Apicultural Research, 49(3): 251-256.

Awad, N. S.; Allam, S. F. M.; Rizk, M. A. and Hassan, M. F. and Zaki, A. Y. 2011. Identification of Varroa mite (Acari: Varroidae) parasitizing honeybee in Egypt using DNA sequencing, morphometric and SEM analysis. Arab J. Biotech., 14(1): 41-48.

Biasolo, A. 1992. Lock of allozyme variability among Varroa mite population. Experimental \& Applided Acarology, 16: 287-294.

Bruce, W. A.; Delfinado-Baker, M. and Vincent, D. L. 1997. Comparative morphology of the peritremes of Varroa and Euvarroa (Varroidae), parasites of honey bees (Apidae). International Journal of Acarology, 23(1):13-20.

De Guzman, L. I.; Delfinado, M. D. and Baker, E. W. 1996. A new species of Varroa (Acari: Varroidae ) associated with Apis koschevnikovi (Apidae: Hy menoptera) in Borneo. International Journal of A carology, 22: 23-27.

De Guzman, L. I.; Rinderer, T. E. and Stelzer, J. A. 1997. DNA evidence of the origin of Varroa jacobsoni Oudemans in the America. Biochemical Genetics, 35: 327-335.

Delfinado, M. D. and Baker, E.W. 1974. Varroidae, a new family of mites on honeybees (Mesostigmata: Acarina). J. Wash. Acad. Sci., 64: 4-9.

Delfinado, M. D.; Baker, E.W. and Aggarwal, K. 1987. A new Varroa (Acari: Varroidae) from the nest of Apis cerana (Apidae). International Journal of Acarology, 13: 233-237.

Fashing, N. J.; Oconnor, B. M. and kitching, R. L.
2000. Lamingtona Carus, a new genus of Algophagidae (Acari: Astigmata) from water filled tree holes in Queensland, Australia. Invertebrate Taxonomy, 14: 591-606.

Issa, M. R. C. 1989. Enzyme patterns in Varroa and Apis from Brazil and Germany. Apidologie, 20: 506-508.

Kraus, B. and Hunt, G. 1995. Differentiation of Varroa jacobsoni Oud. populations by random amplification of polymorphic DNA (RAPD). Apidologie, 26 (4): 283-290.

Lindquist, E. E.; Krantz, G. W. andWalter, D. E. 2009. Order: Mesostigmata. In G.W. Krantz; D. E. Walter (Eds). A manual of acarology. Lubbock; Texas, USA.

Martin, S. J. 2001. The role of Varroa and viral pathogens in the collapse of honeybee colonies: A modelling Approach, J. Appl. Ecol., 38: 1082-1093.

Oldroyd, B. P. 1999. Coevolution while you wait: Varroa jacobsoni, a new parasite of western honeybees. Trends Evol. Ecol., 14:312-315.

Oudemans, A. C. 1904. On a new genus and species ofparasitic acari. Notes from the Leyden Museum 24: 216-222.

Richard, D.; Colin, M. E. and Lhomme, M. 1990. Anatomical organization of the tracheal system of Varroa jacobsoni. Exp. Appl. Acarol., 9: 63-72.

Sammataro, D.; Gerson, U. and Needham, G. 2000. Parasitic mites of honey bees: life history, implications and impact. Annual Review of Entomology, 45: 519-548.

Wienands, A. 1988. The Varroa mite has spread over most of the world. Amer. Bee. J., 128 (5): 358359.

Zaki, A.Y. 2009. Molecular Studies on Genus Varroa (Oudemans) Mite and its control in Egypt. Ph. D., Fac. Agric., Cairo Univ., 128pp. 